\title{
ANALYSIS STRATEGY OF BUILDING UTILIZATION OPTIMIZING IN PUBLIC WORKS TRAINING CENTER REGION IV SURABAYA
}

\author{
Heru Kurniawan, I Putu Artama Wiguna and Retno Indryani \\ Civil Engineering Department, Institute Technology of Sepuluh November \\ Civil Engineering Building 2nd floor, ITS Sukolilo Campus, Surabaya 60111, Indonesia \\ E-Mail: hk24883@gmail.com
}

\begin{abstract}
Public Works Education and Training Center in Region IV of Surabaya is one of work units from education and training center, ministry of public work. It has a role as the organizer of any educational and training as the administrator of non-taxable revenue. Public Works Education and Training Center in Region IV of Surabaya has building which can be used by the internal institute or by the public through the non-taxable revenue fee. However, the property itself is not sufficient compare to the activities held. It caused the utilization of the building is not optimal. The aim of this research is to analyze the strategy of improving the utilization of public work education and training center building area IV Surabaya. The method used in deciding the strategy was by analyzing the internal and external factors through SWOT method. The analysis process of the internal and external factors was done by using the Focus Group Discussion (FGD) method; they were determining the internal and external factors, evaluating them, and developing strategy. The FGD was attended by the internal authorities. By using the Grand Strategy Matrix would be gained the grand strategy of improving the utilization of the building, which then the derivative strategy was analyzed based on the highest score in EFI and EFE matrix. The result is the organization position in the big strategy matrix was in the first quadrant which encourages the aggressive growth. The grand strategies which believed suitable to the organization condition were the market development, market penetration, and product improvement.
\end{abstract}

Keywords: Public Work Education and Training Center in Region IV of Surabaya, SWOT Strategy, Focus Group Discussion, Grand strategy matrix

\section{INTRODUCTION}

Public Works Education and Training Center in Region IV of Surabaya is one of nine Public Works Education and Training Center owned by Ministry of Public Works throughout Indonesia. In implementing main duties and function as Insitution executing educational and training activities, Public Works Education and Training Center in Region IV of Surabaya has asset in the form of office building (Muchtaruddin Office Building), school buildings (Rana and Rio Susilo Buildings) and dormitory buildings (Suhodo and Suryono Buildings), Suhodo and Suryono Buildings, used as lodging for training participants, both regular training and training held by outsiders by leasing. It is possible that it can be used by the leasing party outside the activity or from public needing alternative places to stay.

To improve the service and the comfort of the building users, Public Works Training Center in Region IV of Surabaya continuously performs enhancement of its facilities and infrastructures quality. This activity includes renovation/repairment of classrooms, halls, rooms and surrounding environment and facility replacement to make the building users more comfortable, but the activity is performed periodically up to present. The expectation regarding the enhanced service quality beside making the users more comfortable, it also gives positive impact to Non-Tax State Revenue (PNPB) quotation. It needs a strategy so that the building asset can be utilized optimally, one way is by analyzing internal and external factors influencing the continuity of building asset function.

The objective of thi study is to obtain a proper strategy in improving the utilization of Public Works Training Center in Region IV of Surabaya.

\section{Strategy Management}

Strategy is a long-term goal of a company, and efficiency and allocation of all significant resources to achieve the goal. A good understanding regarding the concept of strategy and other relevant concepts, is strongly determining the success of prepared strategy [2]. Strategy management according to Hunger \& Wheelan (1992) is “.. that set managerial decision and action that determines the long run performance of a corporation, it includes environment scanning, strategic formulation, strategic implementation, evaluation and control"[2]. Meanwhile, according to Lawrence R. Jauch \& W.F Glueck (1984) is “.. a stream of decision and action which development of an affective strategies to help achieve corporate objective"[2]. If it is defined freely, strategy menagement is a number of decisions and actions addressing the preparation of a strategy or a number of effective strategies to help achieve the company's goal [2].

The plan of strategy management for company is a long-term plan based on analysis and diagnosis of internal and external environment which further formulate the analysis result to be a decision of strategy which is the media to achieve the final goal. To determine the main strategy, Fred R. David had developed three stages of work olan with matrix as the analysis model. Device or tool in form of matrix has been suitable with various sizes and types of organization, so that the device can be used by experts in identifying, evaluating and selecting the most proper strategy.

\begin{tabular}{|c|c|c|}
\hline \multicolumn{3}{|c|}{ STAGE 1 : THE INPUT STAGE } \\
\hline External Factor & Competitive Profile & Internal Factor \\
Evaluation (EFE) & Matrix(CPM) & Evaluation \\
Matrix & & (EFI)Matrix \\
\hline
\end{tabular}

\section{LITERATURE REVIEW}


The 2nd International Conference on Civil Engineering Research (ICCER) 2016

\begin{tabular}{|c|c|c|c|c|}
\hline \multicolumn{5}{|c|}{ STAGE 2 : THE MATCHING STAGE } \\
\hline $\begin{array}{l}\text { SWOT } \\
\text { Matrix }\end{array}$ & $\begin{array}{c}\text { Strategic } \\
\text { Position } \\
\text { and Action } \\
\text { Evaluation } \\
\text { (SPACE) } \\
\text { Matrix }\end{array}$ & $\begin{array}{c}\text { Boston } \\
\text { Consulting } \\
\text { Group } \\
\text { (BCG)Matrix }\end{array}$ & $\begin{array}{l}\text { Internal- } \\
\text { Eksternal } \\
\text { (IE)Matrix }\end{array}$ & $\begin{array}{c}\text { Grand } \\
\text { Strategy } \\
\text { Matrix }\end{array}$ \\
\hline \multicolumn{5}{|c|}{ IE DECIS } \\
\hline \multicolumn{5}{|c|}{ Quantitative Strategic Planning Matrix (QSPM) } \\
\hline
\end{tabular}

Figure 1. Framework Analysis Strategy Formulation [2]

There are several stages in the plan of strategy formulation analysis, comprising:

A. Input Stage

In this stage, environment scanning is performed to internal and external factors and competitive situation faced by an organization.

1. Formulation of Internal Factor Evaluation (EFI) Matrix

It is used to evaluate internal factors of an organization related to the strengths and weaknesses owned by the organization which are assumed affecting the success of an organization. Here are the steps of EFI matrix development:

a. Compiling the strenghts and weaknesses of an organization in column (1).

b. Giving weight to each factor in column (2), starting from 0,0 (highly not significant) up to 1,0 (highly significant). mulai dari 0,0 (sangat tidak penting) hingga 1,0 (sangat penting). This weight shows the relative importance of those factors for the success of an organization. The total number of weight is 1,00.

c. Giving rating in column (3) to each factor, strating from 1 (very weak) up to 4 (very strong) based on the organization condition.

d. Multiplying the quality and rating to achieve the weighting factor (in column 4). The result is in form of weighting score for each factor which the value varies strating from 1,0 (very weak) up to 4,0 (very strong).

e. Totalizing the weighting scores to obtain total scores of organization weighting. This total value shows how a certain company reacts to its external strategic factors.

Table 1. Internal Factor Evaluation Matrix [4]

\begin{tabular}{|c|c|c|c|}
\hline \multicolumn{1}{|c|}{ Intemal Factor } & Weight & Rating & Score \\
\hline 1 & 2 & 3 & $4=2 \times 3$ \\
\hline $\begin{array}{c}\text { Strenghts/S: } \\
\text { a. Strenght 1 } \\
\text { b. Strenght 2 }\end{array}$ & $\begin{array}{l}\text { Weight of Streght 1 } \\
\text { Weight of Streght 2 }\end{array}$ & $\begin{array}{c}\text { Rating of Streght 1 } \\
\text { Rating of Streght 2 }\end{array}$ & \\
\hline 1 & 2 & 3 & $4=2 \times 3$ \\
\hline Total Strenght & a & & B \\
\hline $\begin{array}{c}\text { Weaknesses/W : } \\
\text { a. Weakness 1 } \\
\text { b. Weakness 2 }\end{array}$ & $\begin{array}{l}\text { Weight of Weakness 1 } \\
\text { Weight of Weakness 2 }\end{array}$ & $\begin{array}{l}\text { Rating of Weakness 1 } \\
\text { Rating of Weakness 2 }\end{array}$ & \\
\hline Total Weakness & c & & D \\
\hline Total & $(\mathrm{a}+\mathrm{c})=1$ & & (b+d) \\
\hline
\end{tabular}

2. Formulation of External Factor Evaluation (EFE) Matrix

It is used to evaluate external factors of organization by opportunities and threats considered important to the organization continuity. The steps of EFE matrix evaluation are not much different from the formulation of EFI matrix.

\begin{tabular}{|c|c|c|c|}
\hline Extemal Factors & Weight & Rating & Score \\
\hline 1 & 2 & 3 & $4=2 \times 3$ \\
\hline $\begin{array}{c}\text { Opportunities/O : } \\
\text { a. Opportunity 1 } \\
\text { b. Opportunity 2 }\end{array}$ & $\begin{array}{c}\text { Weight of Opportunity 1 } \\
\text { Weight of Opportunity 2 }\end{array}$ & $\begin{array}{l}\text { Rating of Opportunity 1 } \\
\text { Rating of Opportunity 2 }\end{array}$ & \\
\hline Total of Opportunities & a & & B \\
\hline $\begin{array}{c}\text { Threats/T: } \\
\text { c. Threat 1 } \\
\text { d. Threat 2 }\end{array}$ & $\begin{array}{l}\text { Weight of Threat 1 } \\
\text { Weight of Threat 2 }\end{array}$ & $\begin{array}{l}\text { Rating of Threat 1 } \\
\text { Rating of Threat 2 }\end{array}$ & \\
\hline Total of Threat & c & & D \\
\hline Total & $(\mathrm{a}+\mathrm{c})=1$ & & $(\mathrm{~b}+\mathrm{d})$ \\
\hline
\end{tabular}

B. Matching Stage

Strategy is often defined as matching made by an organization between resources and skills and opportunities and risks created by external factors.

1. SWOT matrix is an analysis predicting Strengths and Weaknesses as internal factors, and Opportunities and Threats as external factors influencing the formulation of the strategy which will be used.

\begin{tabular}{|c|c|c|}
\hline EFE & (Strenght - S) & (Weakness $-W)$ \\
\hline (Opportunities $-O)$ & SO Strategy & WO Strategy \\
\hline (Threats $-T)$ & ST Strategy & WT Strategy \\
\hline
\end{tabular}

Picture 2. SWOT Matrix [4]

\section{SPACE (Strategic Posistion and Action Evaluation) Matrix}

SPACE is 4 quadrants plan showing what kind of strategy which is most aggressive, conservative, defensive, or competitive for a certain organization.

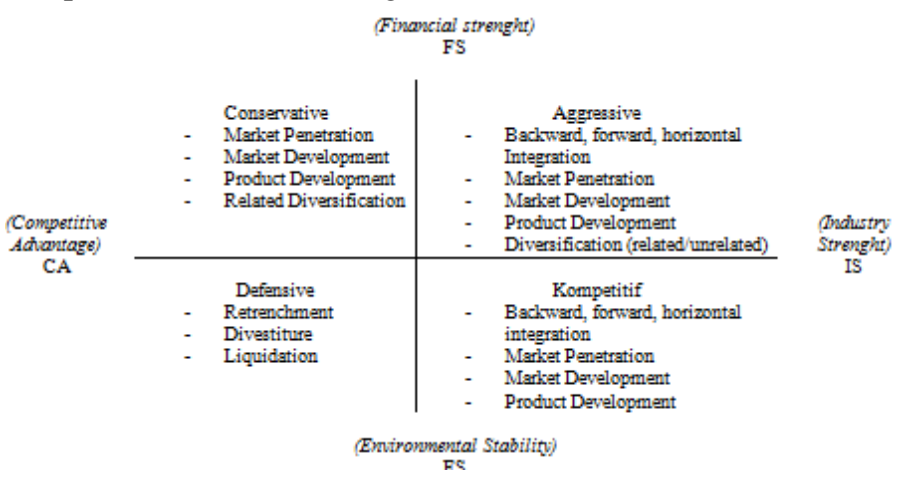

Picture 3. SPACE Matrix [2]

\section{Boston Consulting Group (BCG) Matrix}

BCG Matrix graphically illustrates the difference between divisions in term of market share relative position and level of industrial growth.

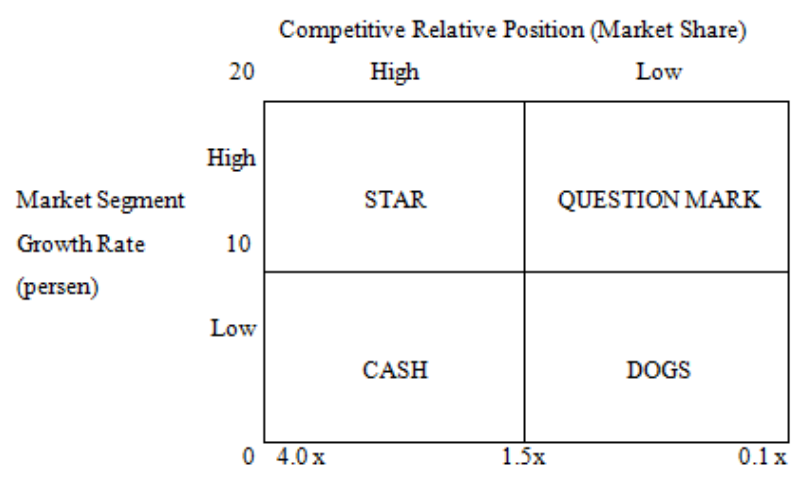

Table 2. External Factor Evaluation Matrix [4] 
Picture 4. BCG Matrix [4]

\section{Internal-Eksternal (IE) Matrix}

IE Matrix is used to put a company business unit into a matrix consisting of 9 cells. IE matrix is based on these two following criteria: scores of EFE matrix - this value is plotted on y axis. Meanwhile, score from EFI matrix is plotted on $\mathrm{x}$ axis, as illustrated in Figure 5.

\begin{tabular}{|c|c|c|c|c|c|}
\hline & & [ot & EFI Wei & ted Scores & \\
\hline & & & Strong & Average & Weak \\
\hline & & 4 & 3 & 2 & 1 \\
\hline EFE & High & 3 & I & II & III \\
\hline Weighted & & & & & \\
\hline Score & Medium & 2 & IV & $\mathrm{V}$ & VI \\
\hline & Low & 1 & VII & VIII & IX \\
\hline
\end{tabular}

Picture 5. Internal-External Matrix [2]

\section{Grand Strategy Matrix}

Based on the scores of analysis result of EFI and EFE matrix obtained, then the organization current position in form of coordinate of point (EFI, EFE) on SWOT quadrant diagram can be illustrated.

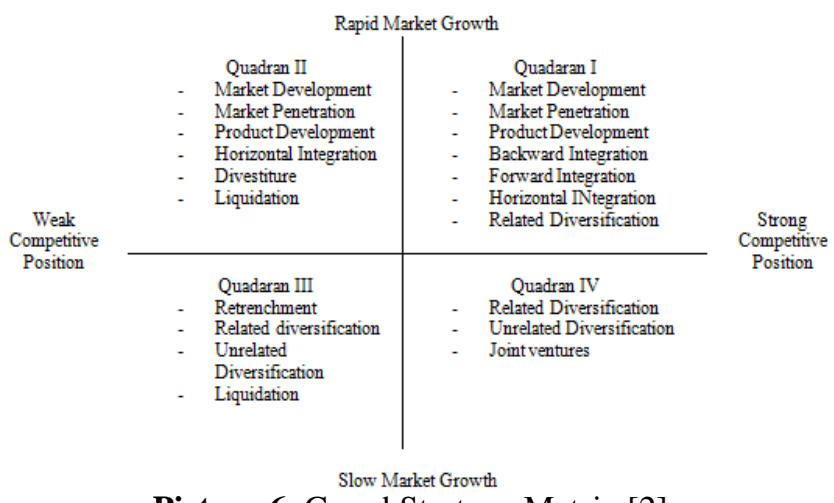

Picture 6. Grand Strategy Matrix [2]

\section{Decision Stage}

The third step is used to evaluate objectively various alternatives produced in matching stage so that it can be implemented

\section{Focus Group Discussion (FGD)}

Focus Group Discussion containes three key words: a. Discussion (not interview or conversation); b. Group (not individual); c. Focused (not free). In definition, although it is basically a discussion, FGD differs from interview, meeting, or conversation done by several people. FGD can be simply defined as a discussion done sistematically and focussed on a certain issue or problem.

\section{MATERIALS AND METHODS}

\section{Materials}

In this study, two types of data are employed, comprising:

1. Primary Data, that is data collected during research from the results of observation, survey, nonstructured direct interview.
- Existing condition of Public Works Trining Center in Region IV of Surabaya

- Internal variable indicator owned by Public Works Training Center in Region IV of Surabaya

- Similar building asset data to obtain similar aset market price:

- Manager data

- General data of building asset (location, environment condition and accessibility)

- Technical data of building asset (Technical \& building width Specification, Number of Residence, supporting facilities

- Data of Residential Rental Fare

2. Secondary Data, that is data obtained through documentation study by examining various writings through relevant literature books, activity report related to asset management and internet media.

- Organization structure of each stakeholder

- Relevant policies / regulations in relation to building utilization / management

- Relevant policies / regulations in relation to estimation and determination of building rental fare

- Management data of Public Works Training Center in Region IV of Surabaya, in form of :

- Building manager data

- Building, room and residence technical data

- Administration data,

- Operational and maintenance cost data (electrical, water, management costs)

- Investment and replacement data

- $\quad$ Service fare, residential rent, laundry and catering or other services fares if any.

Internal and external variable components influencing the determination of building utilization strategy

\section{Methods}

This study is a descriptive study aiming to collect information regarding status of an existing condition and is not intended to test a certain hypothesis [1]. Descriptive study is employed to elaborate the strategy in improving the utilization of building asset without making comparison and relationship between variables.

Interview is used to obtain physical data, management and rental fare in similar asset used to estimate rental fare based on market price. Interview being employed is non-structured direct interview.

Meanwhile, FGD is used to analyse the strategy which is started at the stage of development of internal and external factors influencing the determination of strategy up to the development of alternative strategy.

Based on the identification result of internal and external environment conditions which are further used in the research of strategy analysis and estimation of fare increase of Public Works Training Center Utilization in Region IV of Surabaya.

Table 3. Reasearch Variable

\begin{tabular}{|c|l|l|}
\hline No & \multicolumn{1}{|c|}{ Variable } & \multicolumn{1}{c|}{ Indicator } \\
\hline I & \multicolumn{2}{|c|}{ Internal Factor } \\
\hline A. & \multicolumn{2}{|c|}{ RVB (Resource Based View) } \\
\hline A.1 & Building & Age of building. \\
\cline { 3 - 3 } & & The type of construction built. \\
\hline
\end{tabular}




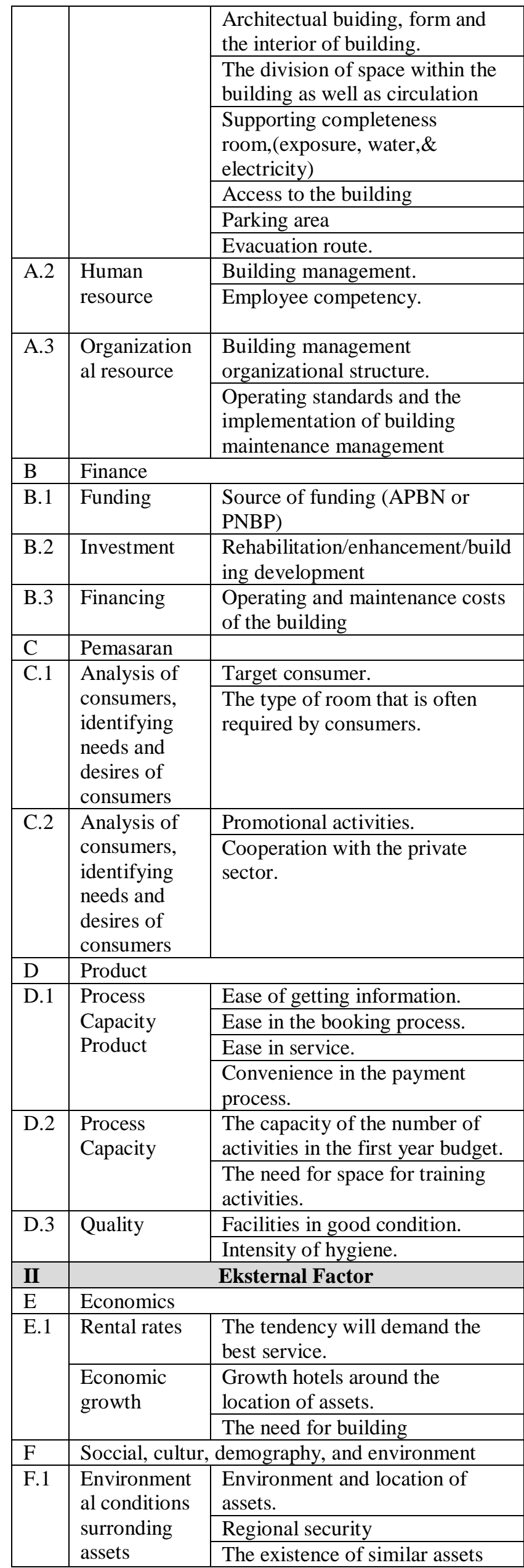

\begin{tabular}{|l|l|l|}
\hline & & $\begin{array}{l}\text { around the site pu training center } \\
\text { region iv surabaya }\end{array}$ \\
\hline F.2 & $\begin{array}{l}\text { Access to } \\
\text { assets }\end{array}$ & $\begin{array}{l}\text { Traffic conditions access to the } \\
\text { location. }\end{array}$ \\
\cline { 3 - 3 } F.3 & $\begin{array}{l}\text { Community } \\
\text { activities }\end{array}$ & $\begin{array}{l}\text { Growth and development of non- } \\
\text { political civic }\end{array}$ \\
\hline G & Political,government, and law \\
\hline G.1 & $\begin{array}{l}\text { Government } \\
\text { regulation }\end{array}$ & $\begin{array}{l}\text { Implementation of policy } \\
\text { meeting. }\end{array}$ \\
\hline H & $\begin{array}{l}\text { Almost every government-owned } \\
\text { training centers perform the } \\
\text { function pnbp provide room } \\
\text { rental service. }\end{array}$ \\
\hline H.1 & $\begin{array}{l}\text { Technologica } \\
\text { l } \\
\text { development }\end{array}$ & $\begin{array}{l}\text { Certificates worthy building } \\
\text { functions. }\end{array}$ \\
\hline & & $\begin{array}{l}\text { Asset information system. } \\
\text { Wifi network. }\end{array}$ \\
\hline & & $\begin{array}{l}\text { Facility with the latest } \\
\text { technology.(AC, PC, LCD, lamp) }\end{array}$ \\
\hline
\end{tabular}

In analysing strategy in this study, SWOT analysis is employed. SWOT analysis is performed by using these following steps:

1. Variable of Study Determination

Variable of study is determined through Focus Group Discussion (FGD). In the way of purposive sampling, FGD participants are the employees of Public Works Training Center in Region IV of Surabaya which are considered influential in making strategic decision and organization management so that the Office Head as the person in charge at the office, Sub-Head of Administration Office as the person in charge in office administration and domesticity manager, Head of Program and Service Section as the person in charge in the field of activity planning and PSPM Officials representing Commitment Making Officials as the financial managers of work unit.

2. Weighting and rating of strategic factors

Scanning to internal and external factors is performed to use Internal Factor Evaluation (EFI) matrix and External Factor Evaluation (EFE) matrix by distributing spreadsheets of weighting and rating to the managers in FGD activity, the steps of analysis are as follows:

a. Each FGD participant fills the spreadsheet of rating and weighting based on the first result of FGD. Scale of rating and weighting uses likert scale 1 up to 4.

b. The result of rating and weighting is recapitulated to further be analyzed regarding the magnitude of weight and rating of each internal and external factor.

c. Recapitulation result of weight and rating on stage "b" is filled in EFI matrix spreadsheet and EFE matrix spreadsheet to obtain internal and external factor scores. The result of this step is the score of total weight for EFI and EFE matrix is obtained.

3. Determining organization position 
By using Grand Strategy Matrix we can determine the position of organization. Position of organization will be mapped into Grand Strategy Matrix in form of cartesian diagram with the number of EFI scores shows coordinate on " $y$ " axis and the number of EFE scores shows coordinate on " $\mathrm{x}$ " axis. By using grand strategy matrix, position of organization is obtained to show which strategy is proper based on its position/quadrant. Here is the division of quadrant of grand strategic matrix, which is:

a. Quadrant 1, will show the strategy supporting aggressive growth policy (growth oriented strategy).

b. Quadrant 2, will show strategy using power to utilize long-term opportunity in the way of market product diversification strategy.

c. Quadrant 3, will show strategy which minimalizes company internal problems so that it can seize better market opportunity.

d. Quadrant 4, an organization facing various internal threats and weaknesses so that the strategy emerging which is to reduce both of them.

4. Strategy Development

Based on Grand Strategy obtained, further is developing Grand Strategy based on organization condition. In the strategy development later will review the main streght and weakness of organization and the biggest opportunity and threat which can influence organization. In this case, the preparation of strategy uses two internal and external factors with the highest score as the reference of strategy determination.

\section{RESULTS AND DISCUSSIONS}

FGD process is performed twice. The result of FGD I execution is the discussion of variables which are influential to strategy determination. Of the eight research variables proposed in the study it can be thoroughly accepted by FGD participants, with notation that there are modification and addition of several subvariables as shown in Table 4.

Table 4. Result of Reasearch Variabel Discussion

\begin{tabular}{|c|c|c|}
\hline \multirow[t]{2}{*}{ No } & \multicolumn{2}{|c|}{ Variable } \\
\hline & Before FGD & After FGD \\
\hline & $\begin{array}{l}\text { RVB (Resource Based } \\
\text { View) }\end{array}$ & $\begin{array}{l}\text { RVB (Resource Based } \\
\text { View) }\end{array}$ \\
\hline & Building & Building condition; \\
\hline & - & $\begin{array}{l}\text { The main supporting } \\
\text { facility; }\end{array}$ \\
\hline & Human resource & Human resource \\
\hline & Organizational resource & $\begin{array}{l}\text { The principal tasks of } \\
\text { organizational }\end{array}$ \\
\hline & - & Strategic location; \\
\hline \multirow[t]{4}{*}{ B. } & Finance & Finance \\
\hline & Funding; & Funding; \\
\hline & Investment & $\begin{array}{l}\text { Financing and } \\
\text { investment; }\end{array}$ \\
\hline & Financing & - \\
\hline \multirow[t]{3}{*}{ C. } & Marketing & Marketing \\
\hline & Consumen analisys & Consumen market; \\
\hline & Sells of product & Marketing activities; \\
\hline
\end{tabular}

\begin{tabular}{|c|c|c|}
\hline \multirow[t]{4}{*}{ D. } & Product & Product \\
\hline & Process & $\begin{array}{l}\text { The process of booking } \\
\text { and payment; }\end{array}$ \\
\hline & Capacity & $\begin{array}{l}\text { Capacity and number of } \\
\text { rooms; }\end{array}$ \\
\hline & Quality & $\begin{array}{l}\text { Quality of facilities and } \\
\text { the facilities in good } \\
\text { condition; }\end{array}$ \\
\hline \multirow[t]{3}{*}{ E. } & Ekonomics & Ekonomics \\
\hline & Tren of low cost rent & Tren of low cost rent \\
\hline & Economic growth & Economic growth \\
\hline \multirow[t]{6}{*}{ F. } & $\begin{array}{l}\text { Social, Cultural, } \\
\text { Demographic and } \\
\text { Environmental }\end{array}$ & $\begin{array}{l}\text { Social, Cultural, } \\
\text { Demographic and } \\
\text { Environmental }\end{array}$ \\
\hline & $\begin{array}{l}\text { Environmental } \\
\text { conditions surrounding } \\
\text { assets }\end{array}$ & $\begin{array}{l}\text { Environmental } \\
\text { conditions surrounding } \\
\text { assets }\end{array}$ \\
\hline & $\begin{array}{l}\text { Access to the location of } \\
\text { assets }\end{array}$ & $\begin{array}{l}\text { Access to the location of } \\
\text { assets }\end{array}$ \\
\hline & Public activity & $\begin{array}{l}\text { Growth and } \\
\text { development of a } \\
\text { community or group } \\
\text { activities }\end{array}$ \\
\hline & & $\begin{array}{l}\text { The existence of similar } \\
\text { assets around the site PU } \\
\text { Training Center Region } \\
\text { IV Surabaya }\end{array}$ \\
\hline & - & $\begin{array}{l}\text { The existence of a } \\
\text { community center and } \\
\text { public facilities }\end{array}$ \\
\hline \multirow[t]{4}{*}{ G. } & $\begin{array}{l}\text { Politik, Pemerintahan \& } \\
\text { Hukum }\end{array}$ & $\begin{array}{l}\text { Politik, Pemerintahan \& } \\
\text { Hukum }\end{array}$ \\
\hline & $\begin{array}{l}\text { Enactment of the } \\
\text { Regulation of the } \\
\text { Minister of Guidance } \\
\text { Restriction Meeting in } \\
\text { hotel }\end{array}$ & $\begin{array}{l}\text { Enactment of the } \\
\text { Regulation of the } \\
\text { Minister of Guidance } \\
\text { Restriction Meeting in } \\
\text { hotel }\end{array}$ \\
\hline & $\begin{array}{l}\text { PNBP executor policies } \\
\text { for government }\end{array}$ & $\begin{array}{l}\text { As implementing } \\
\text { policies that restrict the } \\
\text { acceptance of functional } \\
\text { PNBP types / kinds of } \\
\text { specific consumer }\end{array}$ \\
\hline & $\begin{array}{l}\text { Building inspection have } \\
\text { not been done to get a } \\
\text { Certificates worthy } \\
\text { building functions }\end{array}$ & $\begin{array}{l}\text { Building inspection have } \\
\text { not been done to get a } \\
\text { Certificates worthy } \\
\text { building functions }\end{array}$ \\
\hline \multirow[t]{4}{*}{ H. } & Technology & Technology \\
\hline & Information system & $\begin{array}{l}\text { Development of } \\
\text { information systems } \\
\text { (website) and social } \\
\text { networking media as a } \\
\text { media of information } \\
\text { and promotion }\end{array}$ \\
\hline & Internet connection & - \\
\hline & $\begin{array}{l}\text { Technological } \\
\text { development of } \\
\text { electronic equipment }\end{array}$ & $\begin{array}{l}\text { Technological } \\
\text { development of } \\
\text { electronic equipment }\end{array}$ \\
\hline
\end{tabular}

To obtain factors of stregths, weaknesses, opportunities, and threats for organization, it needs scanning to internal and external environment of organization first. Furthermore, the process of scanning and data collection regarding organization and 
The 2nd International Conference on Civil Engineering Research (ICCER) 2016

"Contribution of Civil Engineering toward Building Sustainable City"

surrounding environment is perfomed by means of observation and survey.

The results of scanning data analysis in internal and external environment (research variables) with the information obtained from FGD I is used as reference in determining the strengths, weaknesses, opportunities and threats of organization in FGD II. The analysis result is shown in Table 5 and Table 6.

Table 5. Result Internal Factor from FGD II

\begin{tabular}{|c|l|c|}
\hline No & \multicolumn{1}{|c|}{ Internal Factor } & \multicolumn{1}{|c|}{$\begin{array}{c}\text { Strenght (S) / } \\
\text { Weakness (W) }\end{array}$} \\
\hline A & Assets, human dan organizational resources \\
\hline A.1 & Strategic location; & S \\
\hline A.2 & Building condition; & W \\
\hline A.3 & $\begin{array}{l}\text { The main supporting } \\
\text { facility; }\end{array}$ & W \\
\hline A.4 & Human resource; & S \\
\hline A.5 & $\begin{array}{l}\text { The principal tasks of } \\
\text { organizational; }\end{array}$ \\
\hline B & \multicolumn{2}{|c|}{ Finance } \\
\hline B.1 & Funding; & Warket \\
\hline B.2 & $\begin{array}{l}\text { Financing and } \\
\text { investment; }\end{array}$ \\
\hline C & \multicolumn{2}{|c|}{ Product } \\
\hline C.1 & Consumen market; \\
\hline C.2 & Marketing activities; \\
\hline D & \multicolumn{2}{|c|}{ S } \\
\hline D.1 & $\begin{array}{l}\text { The process of booking } \\
\text { and payment; }\end{array}$ \\
\hline D.2 & $\begin{array}{l}\text { Capacity and number of } \\
\text { rooms; }\end{array}$ & $\begin{array}{l}\text { Quality of facilities and } \\
\text { the facilities in good } \\
\text { condition; }\end{array}$ \\
\hline D3 & W \\
\hline
\end{tabular}

Table 6. Result External Factor from FGD II

\begin{tabular}{|c|l|c|}
\hline No & \multicolumn{1}{|c|}{ External Factor } & \multicolumn{1}{|c|}{$\begin{array}{c}\text { Oportunity (O) / } \\
\text { Threat (T) }\end{array}$} \\
\hline E & \multicolumn{1}{|c|}{ Economics } \\
\hline E1 & $\begin{array}{l}\text { Tren of low cost rent } \\
\text { E2 }\end{array}$ & $\begin{array}{l}\text { Economic growth is shown } \\
\text { by the growth of hotels }\end{array}$ \\
\hline F & \multicolumn{2}{|c|}{ Social, Cultural, Demographic and Environmental } \\
\hline F1 & $\begin{array}{l}\text { Access to the location of } \\
\text { assets }\end{array}$ & $\mathrm{T}$ \\
\hline F2 & $\begin{array}{l}\text { Environmental conditions } \\
\text { surrounding assets }\end{array}$ \\
\hline F3 & $\begin{array}{l}\text { The existence of similar } \\
\text { assets around the site PU } \\
\text { Training Center Region IV } \\
\text { Surabaya }\end{array}$ & $\mathrm{T}$ \\
\hline F4 & $\begin{array}{l}\text { The existence of a } \\
\text { community center and public } \\
\text { facilities }\end{array}$ \\
\hline F5 & $\begin{array}{l}\text { Growth and development of } \\
\text { a community or group } \\
\text { activities }\end{array}$ \\
\hline G & \multicolumn{2}{c|}{ Politics, Government \& Law } \\
\hline G1 & $\begin{array}{l}\text { Enactment of the Regulation } \\
\text { of the Minister of Guidance } \\
\text { Restriction Meeting in hotel }\end{array}$ & $\mathrm{O}$ \\
\hline G2 & $\begin{array}{l}\text { As implementing policies } \\
\text { that restrict the acceptance of } \\
\text { functional PNBP types / } \\
\text { kinds of specific consumer }\end{array}$ \\
\hline G3 & $\begin{array}{l}\text { Building inspection have not } \\
\text { been done to get a building } \\
\text { functions acceptance }\end{array}$ \\
\hline
\end{tabular}

\begin{tabular}{|c|l|c|}
\hline & certificate & \\
\hline H & \multicolumn{1}{|c|}{ Technology } \\
\hline H1 & $\begin{array}{l}\text { Development of information } \\
\text { systems (website) and social } \\
\text { networking media as a media } \\
\text { of information and promotion }\end{array}$ & $\mathrm{O}$ \\
\hline H2 & $\begin{array}{l}\text { Technological development } \\
\text { of electronic equipment }\end{array}$ & $\mathrm{O}$ \\
\hline
\end{tabular}

Weighting and rating are performed regarding the factors determined in FGD II. Weighting and rating is assessed by FGD participants which are further used as the entry on EFI and EFE Matrix.

Table 7. EFI Matrix

\begin{tabular}{|c|c|c|c|c|}
\hline No. & Internal Factor & Weight & Rating & Score \\
\hline \multirow[t]{2}{*}{ (1) } & (2) & (3) & (4) & $\begin{array}{c}(5=3 \\
x 4)\end{array}$ \\
\hline & Strenght & & & \\
\hline A.1 & Strategic location & 0,070 & 1,50 & 0,105 \\
\hline A.4 & Human resource & 0,098 & 2,25 & 0,220 \\
\hline C.1 & Consumen market & 0,077 & 2,50 & 0,192 \\
\hline C.2 & Marketing activities & 0,077 & 2,50 & 0,192 \\
\hline D.1 & $\begin{array}{l}\text { The process of } \\
\text { booking and payment }\end{array}$ & 0,091 & 3,00 & 0,273 \\
\hline D.3 & $\begin{array}{l}\text { Quality of facilities } \\
\text { and the facilities in } \\
\text { good condition }\end{array}$ & 0,105 & 3,25 & 0,341 \\
\hline \multicolumn{2}{|r|}{ Strenght amount } & 0,517 & & 1,323 \\
\hline \multicolumn{2}{|r|}{ Weakness } & & & \\
\hline A. 2 & Building condition & 0,105 & $-1,75$ & $-0,184$ \\
\hline A.3 & $\begin{array}{l}\text { The main supporting } \\
\text { facilities }\end{array}$ & 0,098 & $-3,25$ & $-0,318$ \\
\hline A. 5 & $\begin{array}{l}\text { The principal tasks of } \\
\text { organizational; }\end{array}$ & 0,070 & $-1,75$ & $-0,122$ \\
\hline B.1 & Funding & 0,070 & $-1,25$ & $-0,087$ \\
\hline B. 2 & $\begin{array}{l}\text { Financing and } \\
\text { investment }\end{array}$ & 0,070 & $-1,50$ & $-0,105$ \\
\hline D.2 & $\begin{array}{l}\text { Capacity and number } \\
\text { of rooms }\end{array}$ & 0,070 & $-1,75$ & $-0,122$ \\
\hline & Weakness amount & 0,483 & & $-0,939$ \\
\hline & Score amount & 1,000 & & 0,385 \\
\hline
\end{tabular}

Table 8. EFE Matrix

\begin{tabular}{|c|c|c|c|c|}
\hline No. & External Factor & Weighting & Rating & Skor \\
\hline (1) & (2) & (3) & (4) & $\begin{array}{l}(5= \\
3 x \\
4)\end{array}$ \\
\hline & Oportunity & & & \\
\hline E.1 & $\begin{array}{l}\text { Tren of low cost } \\
\text { rent }\end{array}$ & 0,106 & 1,75 & 0,186 \\
\hline F.4 & $\begin{array}{l}\text { The existence of a } \\
\text { community center } \\
\text { and public facilities }\end{array}$ & 0,064 & 1,50 & 0,096 \\
\hline F.5 & $\begin{array}{l}\text { Growth and } \\
\text { development of a } \\
\text { community or } \\
\text { group activities }\end{array}$ & 0,078 & 1,50 & 0,117 \\
\hline G.1 & $\begin{array}{l}\text { Enactment of the } \\
\text { Regulation of the } \\
\text { Minister of } \\
\text { Guidance } \\
\text { Restriction Meeting } \\
\text { in hotel }\end{array}$ & 0,085 & 2,25 & 0,191 \\
\hline
\end{tabular}




\begin{tabular}{|c|c|c|c|c|}
\hline H.1 & $\begin{array}{l}\text { Development of } \\
\text { information systems } \\
\text { (website) and social } \\
\text { networking media } \\
\text { as a media of } \\
\text { information and } \\
\text { promotion }\end{array}$ & 0,106 & 2,5 & 0,266 \\
\hline H.2 & $\begin{array}{l}\text { Technological } \\
\text { development of } \\
\text { electronic } \\
\text { equipment }\end{array}$ & 0,092 & 2,5 & 0,230 \\
\hline \multicolumn{2}{|r|}{ Oportunities amount } & 0,532 & & 1,087 \\
\hline \multicolumn{5}{|c|}{ Threat } \\
\hline E.2 & $\begin{array}{l}\text { Economic growth is } \\
\text { shown by the } \\
\text { growth of hotels }\end{array}$ & 0,078 & $-1,00$ & $\begin{array}{c}- \\
0,078\end{array}$ \\
\hline F.1 & $\begin{array}{l}\text { Access to the } \\
\text { location of assets }\end{array}$ & 0,064 & $-1,25$ & $\begin{array}{c}- \\
0.080\end{array}$ \\
\hline F.2 & $\begin{array}{l}\text { Environmental } \\
\text { conditions } \\
\text { surrounding assets }\end{array}$ & 0,064 & $-1,25$ & $\begin{array}{c}- \\
0,080\end{array}$ \\
\hline F.3 & $\begin{array}{l}\text { The existence of } \\
\text { similar assets } \\
\text { around the site PU } \\
\text { Training Center } \\
\text { Region IV Surabaya }\end{array}$ & 0,071 & $-1,25$ & $\begin{array}{c}- \\
0,089\end{array}$ \\
\hline G.2 & $\begin{array}{l}\text { As implementing } \\
\text { policies that restrict } \\
\text { the acceptance of } \\
\text { functional PNBP } \\
\text { types / kinds of } \\
\text { specific consumer }\end{array}$ & 0,092 & $-1,75$ & $\begin{array}{c}- \\
0,161\end{array}$ \\
\hline G.3 & $\begin{array}{l}\text { Building inspection } \\
\text { have not been done } \\
\text { to get a building } \\
\text { functions } \\
\text { acceptance } \\
\text { certificate }\end{array}$ & 0,099 & $-3,00$ & $\begin{array}{c}- \\
0,298\end{array}$ \\
\hline \multicolumn{2}{|r|}{ Threats amount } & 0,468 & & $\begin{array}{c}- \\
0,785\end{array}$ \\
\hline & Score amount & 1,000 & & 0,301 \\
\hline
\end{tabular}

By using Grand Strategic Matrix, organization condition can be determined by means of integrating total scores of internal and external factors into the matrix. The total scores of internal factor show $y$ axis, whereas the total scores of external factor show $\mathrm{x}$ axis. For the total scores of internal factor is obtained 0,385 and for the total scores of external factor is obtained 0,301. Based on mapping result of coordinate of point is obtained that organization position is located in quadrant I which is quadrant where organization/company has a perfect strategic position. Organization in quadrant $\mathrm{I}$ is organization having excess adequate resources to benefit from various external opportunities emerging.

Grand strategy for organization included in quadrant I are market development, market penetration, product development, forward integration, backward integration, horizontal integration and relevant diversification.

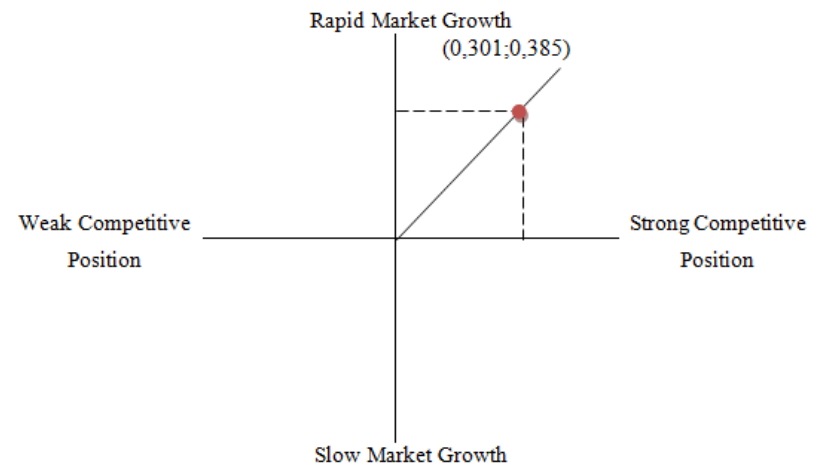

Picture 6. Grand Strategy Matrix

To obtain descendant strategy based on grand strategy acquired, then score result of EFI and EFE matrix is analyzed. By observing the result of data tabulation of EFI and EFE matrix, it is selected three strenghts and three weaknesses with the biggest score on internal factor and three opportunities and treats with the biggest score on external factor, respectively, to be used as root in developing strategy pursuant to Grand strategy.

Table 9. Developing Alternative Strategy

\begin{tabular}{|c|c|c|}
\hline $\begin{array}{c}\text { Grand } \\
\text { Strategy }\end{array}$ & Alternative Strategies & $\begin{array}{c}\text { Basic } \\
\text { Decision }\end{array}$ \\
\hline $\begin{array}{l}\text { Market } \\
\text { development }\end{array}$ & $\begin{array}{l}\text { - Cooperating with civil } \\
\text { servants to carry out } \\
\text { training activities by } \\
\text { providing training devices } \\
\text { such as curricula, modules, } \\
\text { teaching materials and } \\
\text { instructor }\end{array}$ & $\begin{array}{l}\text { According } \\
\text { to S6, S5, } \\
\text { O4, T5 }\end{array}$ \\
\hline $\begin{array}{l}\text { Market } \\
\text { penetration }\end{array}$ & $\begin{array}{l}\text { - Contacting previous } \\
\text { customers to implement } \\
\text { cooperation. There will be } \\
\text { a new tariff scheme with } \\
\text { the addition of facilities } \\
\text { and room services, such as } \\
\text { for training activities / } \\
\text { meetings will be given } \\
\text { training kit / tool kit } \\
\text { - To improve the promoting } \\
\text { to the private sector }\end{array}$ & $\begin{array}{l}\text { According } \\
\text { to S2, S6, } \\
\text { O5, O4, T5 }\end{array}$ \\
\hline $\begin{array}{l}\text { Product } \\
\text { development }\end{array}$ & $\begin{array}{l}\text { - Fixing products by } \\
\text { renovating on the old } \\
\text { components of building } \\
\text { (room / classroom / } \\
\text { auditorium) in order to } \\
\text { fulfill current market } \\
\text { demand }\end{array}$ & $\begin{array}{l}\text { According } \\
\text { to W1, } \\
\text { W2, T4, } \\
\text { T6 }\end{array}$ \\
\hline
\end{tabular}

To implement the alternative strategy, follow-up is necessary in form of:

1. Increasing electrical data, anticipating electrical use at maximum usage.

2. Increasing clean water supply. To overcome the lack of clean water supply from PDAM then make a cooperation with private party selling clean water from ridge (water tank truck) then store it in reservoir, thus reservoir establishment is needed, it can be in form of either open stock or underground stock. The use of drilling well can be employed to 
satisfy the field necessity because the groundwater quality in Surabaya is less good.

3. Rehabilitating building by doing renovation on the old components of building such as wall, floor covering, sills-sash \% door, renovation of bathroom and architecture parts (interior and exterior). This activity is performed in the same direction with rehabilitating room, classroom and hall conditions to make the appearance more representative.

4. Completing facilities of service in rooms, classrooms, and halls such as bathroom fittings, food/snack, training kit/tool in the classroom/hall.

5. Developing website-based information system used as information and promotion media.

6. Adding one marketer who is also as website manager.

7. If necessary, cooperation scheme with the provision of training activity package, then curriculum, modules and teaching material and instructors are required.

\section{CONCLUSIONS}

Based on the results of this study the following conclusions are drawn:

1. Organization position of Public Works Training Center based on grand strategy matrix mapping is located on quadrant I which is quadrant where organization/company has a perfect strategic position. Organization having excess adequate resources to benefit from various external opportunities emerged.

2. A proper strategy for Public Works Training Center in enhancing building utilization can be taken from the analysis result of Grand Strategy in term of: Market Development that is performing cooperation with other organizations or parties, market penetration that is by new fare scheme making along with the addition of service and facilities, and product Development by renovating rooms/classrooms/hall to be able to satisfy current demand of market.

\section{REFERENCES}

[1] Arikunto, S. 2003. Manajemen Penelitian. PT. Rineka Cipta, Jakarta.

[2] David, F. R. 2012. Manajemen Strategis : Konsep (Edisi 12). PT. Salemba Empat. Jakarta.

[3] Purwanto, I. (2008), Manajemen Strategi. CV. Yrama Widya. Bandung.

[4] Rangkuti, F. 2008. Analisis SWOT : Teknik Membedah Kasus Bisnis. PT. Gramedia Pustaka Utama. Jakarta. 